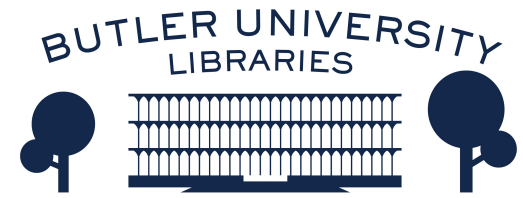

Butler University

Digital Commons @ Butler University

2019

Climate Change Mitigation and the U.N. Security Council: A Just War Analysis

Harry van der Linden

Follow this and additional works at: https://digitalcommons.butler.edu/facsch_papers

Part of the Ethics and Political Philosophy Commons 
Published in Jennifer Kling, editor, Pacifism, Politics, and Feminism (Leiden / Boston: Brill and

Rodopi, 2019), pp. 117-136 (chapter 7).

\title{
Climate Change Mitigation and the U.N. Security Council: A Just War Analysis
}

\author{
Harry van der Linden
}

\section{1.}

Prior to the agreement on climate change adopted in December 2015 in Paris during the twentyfirst session of the Conference of Parties (COP 21), under the auspices of the United Nations Framework Convention on Climate Change (UNFCCC), quite a few scholars had discussed and favored a robust role of the U.N. Security Council (UNSC) in bringing about effective global greenhouse gas (GHG) mitigation. More hesitantly, some have supported the UNSC authorizing military action against countries failing to mitigate in an adequate manner. ${ }^{1} \mathrm{I}$ will argue here that the shortcomings of the Paris Agreement are such that providing the UNSC with the authority to enforce climate change mitigation through military coercion remains a significant option. To be sure, the recent decision of the Trump administration to seek withdrawal from the Paris Agreement means that the United States, for the time being at least, will likely veto any UNSC authorization of military action aimed at climate change mitigation, but a vetoed decision would still put moral and political pressure on countries with poor mitigation records, including the United States, to improve their record. Also, a vetoed decision would be significant in providing moral support for similarly motivated military action toward climate change mitigation outside

1. Lango, "Global Ethics and Global Climate Change," supports UNSC authorization of military action as a last resort measure, especially if the UNSC would become more representative; Scott, "The Securitization of Climate Change in World Politics," views it as potentially beneficial and focuses on the likelihood of it happening (which she views as low); $\mathrm{Ng}$, "Safeguarding Peace and Security in our Warming World," briefly notes some problems with a military response but she does not want to exclude it; and Christiansen, Climate Conflicts, argues generally that future UNSC military authorization might be justified. Cousins, "UN Security Council," maintains that UNSC coercive climate action is legally feasible but politically unrealistic, leading her to favor the UNSC playing a peaceful conflict resolution role between states with opposed adaptation and mitigation goals. Finally, Gilley and Kinsella, "Coercing Climate Action," think UNSC authorization is unlikely but hold that limited military force might be justified by countries as an act of individual or collective self-defense. 
the UNSC framework. I will argue, however, that the option of the UNSC coercing GHG mitigation is morally flawed and ultimately antithetical to effectively addressing climate change. My assessment will be based significantly on jus ad bellum principles of the just war tradition, taking into account some feminist critiques of this tradition. Relatedly, I will briefly contest Bill McKibben's proposal that we should view climate change as a third world war, requiring a mobilization similar to the one undertaken to defeat fascism in World War II. More broadly, I will argue in conclusion that "war is not the answer" with regard to avoiding disastrous climate change; rather, hope is to be found in massive nonviolent resistance to non-mitigating countries and increased local efforts of adopting green technologies.

\section{2.}

Understandably, after more than two decades of failed global climate change negotiations, the Paris Agreement was widely praised and even celebrated in the public media. Yet the Agreement failed to live up to its proclaimed aim [stated in Article 2 (a)] of "holding the increase in the global average temperature to well below $2^{\circ} \mathrm{C}$ above pre-industrial levels and to pursue efforts to limit the temperature increase to $1.5^{\circ} \mathrm{C}$ above pre-industrial levels." The problem is that the promised GHG mitigation goals, including both reduced GHG emissions and larger GHG sinks, as voluntarily set by most states participating in COP 21 fall far short of ensuring this aim and are expected to lead to as much as $3^{\circ} \mathrm{C}$ rise in global average temperature by the end of the century. ${ }^{2}$ The Paris Agreement seeks to deal with this problem by committing states to adjust and improve every five years, beginning in 2020, their mitigation goals, which are called "Nationally Determined Contributions" (NDCs), and this process is supposed to continue until the aim of global average temperature increase well below $2^{\circ} \mathrm{C}$ is met. Will this process be effective?

On a positive note, the ratification of the Paris Agreement required that at least 55 countries accounting for at least 55\% of global GHG emissions signed the Agreement, and this requirement was met in early October 2016. Thus the Agreement went into force on November 4, 2016. A crucial step toward ratification was that China and the United States at the G20 summit in China (September 2016) provided notice of ratification. A worry was that (former) President Obama sidestepped the treaty confirmation role of the Senate in the ratification process, reflecting that the Senate might not have ratified the Paris Agreement due to general Republican

2. See Climate Action Tracker, "Global Temperatures." 
hostility to GHG mitigation. This hostility was again on display in broad Republican support in Congress for President Trump's decision on June 1, 2017, to withdraw from the Paris Agreement.

In his withdrawal announcement, Trump defended his decision primarily by arguing that "the Paris Climate Accord is simply the latest example of Washington entering into an agreement that disadvantages the United States to the exclusive benefit of other countries." Trump specifically mentioned that the Paris Agreement allows China "to increase [its] emission by a staggering number of years - 13," while "India makes its participation contingent on receiving billions and billions and billions of dollars in foreign aid from developed countries." $\mathrm{He}$ continued: "There are many other examples. But the bottom line is that the Paris Accord is very unfair, at the highest level, to the United States." Trump echoed here a complaint of unfairness launched by the United States since the earliest attempts to negotiate a climate change agreement centered on the notion that different demands should be placed on developed and developing countries since the developing countries have shorter histories of significant GHG emissions than most developed countries and so are lesser contributors to climate change, have much lower per capita emissions than most developed countries, and seek rapid growth, if necessary with cheap fossil fuels (as did once the developed countries). The problem with the Paris Agreement is not lack of fairness, but that the peak emissions of most developed nations are not reduced quickly enough and that those of China are delayed until 2030 and those of India have an open-ended date, making projected global mitigation fall short of the goal of keeping the global temperature increase well below $2^{\circ} \mathrm{C} .{ }^{3}$ What adds to the problem is that the Green Climate Fund, established in 2010 (at COP 16) to enable developing countries such as India to adopt green technologies more rapidly (and also assist in the adaptation to climate change), might not be large enough to sufficiently reduce their peak emissions at an early enough date. Surely, the Trump administration has added to this problem by refusing to fulfill the initial American pledge, grossly overstated by Trump, of 3 billion, 1 billion of which was paid by the Obama administration.

3. See Climate Action Tracker, "Rating countries." Ironically, Trump in his withdrawal speech also notes the inadequacy of the Paris Agreement. He overstates the issue, claiming that the agreement will reduce global temperatures only by $0.2^{\circ} \mathrm{C}$, and then argues that the economic costs for the United States are not worth it. Trump's argument does not mean that he takes anthropogenic climate change seriously now (after having called it a "hoax" on earlier occasions); after all, no mention is made in his speech of how to address climate change other than a vague and unrealistic claim that he is prepared to renegotiate the Paris Agreement. 
The long-term impact of the American withdrawal from the Paris Agreement is uncertain. The withdrawal will not be completed until close to the next presidential election and new leadership might re-engage with the Agreement. The negative impact of the withdrawal and the support of the Trump administration for weakening EPA regulations affecting GHG emissions and expanding fossil-fuel extraction, including coal, within the United States will to some extent be offset by the fact that a large number of state governments, such as California and New York, and numerous cities have declared to uphold the Paris mitigation target of the United States or go beyond it. China and the EU might also in response to the withdrawal accelerate the implementation of their mitigation goals. ${ }^{4}$ Still, the withdrawal of the United States as the world's second largest GHG emitter is a clear setback and might lead other countries to weaken their renewable energy endeavors. More generally, the rise of nationalism and rightwing populism does not bode well for the articulation of NDCs focused on the interest of future generations rather than on short-term national interests. In short, the Paris Agreement might not only fail to meet its ultimate temperature reduction aim, but it also might fail to realize even its current NDC promises. Once the Agreement unravels, the world might be on its way, in a manner that could be largely irreversible, from severe climate change (occurring with a $3^{\circ} \mathrm{C}$ increase in global average temperature) to catastrophic climate change (occurring with an increase in global average temperature above $\left.5^{\circ} \mathrm{C}\right) .{ }^{5}$ The Paris Agreement offers little to prevent its unraveling since it lacks any enforcement mechanism other than the public naming and "shaming" of countries that fail to meet or improve their NDCs. ${ }^{6}$

\section{3.}

In light of the weaknesses of the Paris Agreement, the uncertainly created by American withdrawal, and the extreme urgency of effectively addressing climate change in the coming decades, it is important to consider recent proposals to the effect that the UNSC should address

4. See Boffey and Neslen, "China and EU respond to Trump with a new climate alliance."

5. See Campbell and Parthemore, "National Security and Climate Change in Perspective."

6. The Paris Agreement does not cover aviation and international shipping, each accounting for as much as $3 \%$ of human-caused climate change. It is unclear at this moment whether the Trump administration will disregard various international arrangements (partly in progress) to reduce the climate change impact of these sources. In October 2016, the signatories of the 1987 Montreal Protocol eliminating the ozonedepleting CFC refrigerants agreed to gradually phase out most of the current use of HFC refrigerants by 2045. HFCs are also extremely harmful GHGs. It seems that the Trump administration will uphold this amendment. 
climate change, including the most far-reaching suggestion that the UNSC take coercive political, economic, and military measures (Chapter VII measures) against individual states failing to mitigate. Certainly, we should expect that the voices for more UNSC involvement will become stronger if the Paris Agreement would begin to fall apart.

Placing the authority to respond to countries with poor mitigation records in the hands of the UNSC seems a logical and final step of the so-called "securitization of climate change." In the words of international relations scholar Shirley V. Scott, "securitization [in general] involves referring to an issue that has hitherto been conceptualized 'only' in political, economic, environmental or other terms as a security threat so as to heighten awareness of the issue and the urgency of taking effective action."7 Examples other than climate change are the securitization of pandemic diseases and environmental degradation (such as loss of bio-diversity). The process of the securitization of climate change has been under way for some time. The UNSC debated climate change for the first time on April 17, 2007, and subsequently in 2011, 2013, and 2015. Overall, it seems that most countries from the Global South (G77) participating in these debates opposed making climate change an UNSC issue in any form, presumably being wary of "Western interventionism," while many supporting countries of the North typically favored some non-coercive UNSC role. ${ }^{8}$ Still, there has also been a growing recognition among UNSC members (as well as within the UN at large) that global warming is a "threat multiplier" in that the effects of global warming, such as reduced resources (water, arable land, food), economic damage and land loss due to rising sea levels, and migration caused by environmental degradation, may deepen existing tensions and conflicts, both within and between states. ${ }^{9}$ And at a March, 2015, UNSC meeting, initiated by New Zealand, a sympathetic hearing was given to the concern of small island states that climate change, by causing rising sea levels and increased tropical storms, goes beyond being a threat multiplier and poses for them a direct existential security threat. ${ }^{10}$ In other words, climate change may not only increase sources of conflict, but may also pose a direct threat to state sovereignty and territorial integrity. Furthermore, the U.S. government and the Department of Defense (DoD) have recognized the security implications of

7. Scott, "The Securitization of Climate Change in World Politics," 221.

8. See Cousins, "UN Security Council," 201-05. The notable exceptions among the G77 countries are the small island states, such as the Republic of Maldives.

9. See Scott, "The Securitization of Climate Change in World Politics," 225-226. See also Gilley and Kinsella, "Coercing Climate Action," 13.

10. See Climate Home, "UN Security council hears climate fears of small island states." 
climate change, addressing the issue in the National Security Strategy of 2015 and the DoD's Climate Change Adaptation Roadmap (2014) and its National Security Implications of ClimateRelated Risks and a Changing Climate (2015). ${ }^{11}$ More specifically, it is widely acknowledged that the current conflict in Syria that began in 2011 has been partly caused by social and political unrest rooted in its climate change-related extreme drought between 2007 and 2010.

Since climate change has undeniable security consequences, the UNSC, if it has not already done so, will sooner or later adopt Chapter VII measures in response to conflict caused or worsened by climate change. ${ }^{12}$ Such UNSC measures would fall basically within the sphere of adaptation to climate change since the focus is on addressing the negative consequences of this change. ${ }^{13}$ Full securitization of climate change, however, would go beyond this type of action toward the enforcement of mitigation standards necessary to prevent irreversible severe or catastrophic climate change. In other words, the shift is from addressing only the consequences of climate change toward also addressing its causes. ${ }^{14}$ One way to envision this full securitization is that the UNSC would take Chapter VII measures with regard to states that fail to meet their NDCs or fail to make necessary adjustments to their NDCs at future COP meetings. Alternatively, the UNSC could set a global standard concerning the allowable per capita GHG emissions (with the aim of limiting global warming to well below $2^{\circ} \mathrm{C}$ ) and adopt coercive measures against countries failing to meet this standard (even after they have acquired tradable GHG emissions permits from low-emitting countries). No doubt, this latter approach would be in theory more effective in curtailing climate change, but it would also be less feasible (both in terms of arriving at standards and enforcing them), and so let me focus on the first approach. ${ }^{15}$ Let me call a state that fails to meet or improve its NDC a "non-mitigator." The non-mitigator may be a free-rider or blindly hope that future technology will solve the problem; or the failure to mitigate adequately may be rooted in a denial of climate change or in the conviction that

11. The DoD reports are also concerned with how the U.S. military can reduce its GHG footprint and how it should anticipate changes in its operations due to climate change, such as rising sea levels.

12. Scott suggests that the UNSC already passed a Chapter VII measure with Operation Restore Hope in response to the crisis in Somalia partly caused by climate change-induced drought. See "The Securitization of Climate Change in World Politics," 223.

13. See Scott, "Implications of climate change for the UN Security Council," 1321, 1326.

14. Ibid., 1326.

15. Cf. Ng, "Safeguarding Peace and Security in our Warming World," 292, who argues that instead of the UNSC setting its own standards, it would be better for the UNSC to enforce the mitigation standards of the Kyoto Protocol or any future climate agreement. 
climate change is not significantly caused by human conduct. So, on this account, the United States is becoming a non-mitigator under the Trump administration, and India continuing on a course of economic nationalism and/or receiving inadequate international support for green technologies might become a non-mitigator. A full securitization of climate change would mean that the UNSC would consider Chapter VII measures against non-mitigators. Conceivably, the UNSC could also play a role in the enforcement of creating climate funds for mitigation and adaptation in developing countries, and it could create a tribunal for political leaders committing the crime of non-mitigation. Moreover, the UNSC also could take Chapter VI ("Pacific Settlement of Disputes") measures when disputes rooted in climate change would emerge. However, I will focus here on the following question: In case that the Paris accord would begin to unravel, should we support the UNSC taking military measures (after political and economic coercion has failed) to discourage and modify non-mitigators?

\section{4.}

A clear cost of this kind of full securitization of climate change is reduced participation by states in deciding an effective climate change regime and coercive measures taking the place of voluntary cooperation. ${ }^{16}$ The Paris Agreement involved the participation and cooperation of the community of states with most states articulating national mitigation goals to get the process going, and its ratification also required the explicit voluntary commitment of many states. The full securitization of climate change, to the contrary, places the responsibility of states to avoid severe or catastrophic climate change significantly in the hands of a small group of countries, the five permanent members of the UNSC and its additional ten rotating members, and this more limited participation of states will lead to coercive UNSC resolutions. What would offset the costs of reduced participation is that the UN General Assembly would initiate or encourage action against non-mitigators on basis of article 11 (3) of the U.N. Charter, allowing it to "call the attention of the Security Council to situations which are likely to endanger international peace and security." 17 At any rate, the costs would not constitute a decisive objection to full

16. Cf. Scott, "The Securitization of Climate Change in World Politics," 222-23.

17. Cf. Lango, "Global Ethics and Global Climate Change." The General Assembly adopted a much weaker resolution in 2009 (GA Res. 63/281), maintaining that the UNFCCC is the "key instrument" addressing climate change but also calling on all relevant $\mathrm{UN}$ bodies to consider the security implications of climate change. Cousins, "UN Security Council," 202, cites this resolution but neglects to note that the 
securitization of climate change if we were to conclude that UNSC climate action would be both effective and necessary in order to prevent the ravages of severe or catastrophic climate change. On the precipice, it might be justified to replace the persuasion of words by the persuasion of (threat of) weapons.

However, does the UNSC, on the basis of the U.N. Charter, have the legal authority to adopt a resolution to resort to force, or to use the threat of force, in order to coerce nonmitigators to mend their ways? In addressing this question, it is instructive to examine how Silke Marie Christiansen justifies a GHG mitigation role for the UNSC in her Climate Conflicts. On her account, the UNSC may authorize military measures when article 2 (4) of the U.N. charter prohibiting all members from "the threat or use of force against the territorial integrity or political independence of any state" - is violated. Controversially, Christiansen argues that we should interpret the "use of force" not just as involving the use of military force, but more broadly as collective human behavior that threatens or leads to the violation of state sovereignty. Most dramatically, states responsible for climate change cause this kind of violation when rising sea levels lead to loss of territory or even threaten statehood as in the case of such small island states as the Republic of Maldives. Christiansen notes that a problem with this analysis of the "use of force" is that damaging operations of nature caused by climate change, unlike military attacks, "are not necessarily humanly intended." 18 She responds that, in the future at least, large GHG emitters may be construed as hostile once green technologies become more readily available, affordable, and are not used by them on a wide scale. Thus Christiansen concludes that the UNSC should at least have a future role in responding coercively and militarily to such major hostile emitters. ${ }^{19}$

A difficulty of Christiansen's analysis is that it does not seem to offer a convincing guideline concerning which countries should possibly be subjected to UNSC actions. Unlike a military attack, climate change as "use of force" is foremost an emerging threat that will not fully materialize for many decades. To be sure, serious environmental damages are already occurring, as well as numerous human casualties, but they are small as compared to anticipated future

GA reaffirmed the central role of the UNFCCC.

18. Christiansen, Climate Conflicts, 183.

19. Ibid., 184. See also ibid., 244. Christiansen argues against the idea that climate change is a threat that might trigger the right to self-defense against "armed attack" articulated in article (51) of the U.N. Charter because, among other reasons, "defining the emission of GHGs as armed attack will definitely overstretch the meaning of article 51" (ibid., 185). 
harms if GHG emissions continue on their current trajectory. Looking to past GHG emissions, it would be hard to single out particular states as responsible for climate change since most states have contributed to the unfolding threat of rising sea levels for, say, the Republic of Maldives, and no specific state by itself made the difference so that it alone could be held responsible for the environmental threat. Of course, all major historical emitters could be collectively held responsible, but then who would authorize and execute UNSC resolutions against this collective? Looking forward to future GHG emissions, the main historical emitters are not necessarily the ones who will satisfy the requirement of hostile intention because they may adopt green technologies on a broad scale, while large future emitters with hostile intention might be overall less responsible for climate change than the main historical emitters because they might have limited GHG emission histories. And what further complicates the issue is that GHG emissions in one country (e.g., China) might be significantly caused by its production for export, placing the responsibility for the emissions partly in the hands of the importing countries.

UNSC action against states failing to adhere to, or improve, their NDCs seems largely to avoid these difficulties of determining which countries should be liable to UNSC action. The UNSC has the legal authority to respond to "any threat to the peace, breach of the peace, or act of aggression" (article 39). To view climate change as an act of aggression or a breach of the peace is questionable, but it is clearly a threat to the peace. We need not establish differential responsibility for causing this threat on basis of the GHG emission records of individual states. Instead, it suffices to note that the Paris Agreement seeks to reduce and prevent the threat. Nonmitigators risk the unraveling of the Paris Agreement and so they pose a threat to the peace and are subject to UNSC action. The shift here is significantly from backward-looking responsibility and blame for climate harm to forward-looking responsibility for contributing to preventing climate harm, a shift that facilitates and encourages cooperation. ${ }^{20}$ However, blame becomes appropriate again with regard to non-mitigators, and the scale of GHG emissions remains morally relevant because the risk of the unraveling of the Paris Agreement will increase the greater role a non-mitigator has to play in reducing global GHG emissions. The UNSC in seeking to uphold the Paris Agreement should first implore non-mitigators to solve their dispute

20. See Young, Responsibility for Justice. Following Young, climate change is a structural injustice and she argues that such injustices are best solved by switching from a backward-looking discourse of blame for the injustice toward a forward-looking discourse of taking on responsibility for eliminating the injustice. 
about their NDCs with other parties to the accord in a peaceful manner (Chapter VI measures), and if this would fail, Chapter VII measures culminating in military action would be appropriate.

A serious problem with the UNSC authorizing military measures with regard to climate change is that three (China, the United States, and Russia) of the current top five GHG emitters (also including the E.U. and India) have veto power as permanent members of the UNSC (and France may veto on behalf of the E.U.). Thus, even if the non-permanent members would have a strong green agenda, the military measures would inevitably be selective and exclude some potential large non-mitigators. Generally, one would expect military actions are more likely to be authorized against militarily weaker non-mitigating countries, which also tend to be smaller GHG emitters. Accordingly, it is not surprising that, overall, countries from the Global South, even though they are likely to be the greatest victims of severe or catastrophic climate change because these countries will have fewer resources to deal with its negative impacts, have been least sympathetic to putting climate change on the UNSC agenda, fearing Western interventionism and neo-colonialism. Most immediately, UNSC military action against nonmitigators is not to be expected since the United States as non-mitigator will not only veto any resolution against itself but also will likely veto any UNSC military action against other countries in order to avoid appearing blatantly hypocritical.

Still, the option of considering UNSC military action against non-mitigators remains relevant for several reasons. First, the United States may rejoin the Paris Agreement and, so, military coercion against countries that willfully ignore their NDCs may become feasible. To be sure, this coercion would likely be selective and aimed at smaller military powers, but a case could be made that non-mitigating small countries set a bad precedent and the extreme urgency of addressing climate change outweighs the selectivity problem. Second, even if the United States were to veto all UNSC resolutions concerning military coercion against non-mitigators, a vetoed decision would still put moral and political pressure on non-mitigators to improve their record. Third, a vetoed resolution would offer moral support for mitigating countries to engage in military coercion against non-mitigators outside the UNSC framework. Certainly, repeated vetoed decisions would gradually create a norm of when military action against non-mitigators would be justified. We may then anticipate that this norm would come to guide military action executed and approved by a large majority of mitigating counties against non-mitigators. 


\section{5.}

This brings us to the crux of the matter: Can military force authorized by the UNSC against nonmitigators be morally justified? This question, unlike the issues of whether the UNSC in fact will increasingly be concerned with climate change and has the legal authority do so, has not yet received much attention. ${ }^{21}$ Let me address this question on basis of just (resort to) war (jus ad bellum) principles, keeping in mind that the analysis bears more broadly on how we view the idea of (military) violence for the sake of combatting climate change. I have already addressed to some extent the jus ad bellum requirement that resort to military force must be decided by a legitimate authority - that is, an authority with moral competency and legitimacy. The UNSC has the legal authority to initiate military action against non-mitigators, but the veto system weakens its moral authority in that a more representative UNSC without the veto system is more likely to arrive at impartial decisions, taking into account a broader range of voices and interests.

Another problem with the moral authority of the UNSC is that this body lacks any articulated standards for deciding whether in a particular case resort to force is morally warranted. Notably, the UNSC did not adopt in 2005 "five criteria of legitimacy" recommended in A More Secure World, Report of the UN Secretary General's High-level Panel on Threats, Challenges, and Change. These criteria are similar to common jus ad bellum principles, and in the absence of such criteria UNSC resolutions might be decided by power politics rather than by seeking justice. Accordingly, UNSC resort to force against non-mitigators will inevitably raise the doubt that the decision might not accord with the jus ad bellum principle of right intention, requiring that both the decision to resort to military action and its execution are guided by justice, not extraneous political interests.

A third jus ad bellum principle is that military action should have a reasonable chance of success. Success in the present context would mean that as a result of UNSC-initiated military action a non-mitigator would come to adopt adequate GHG mitigation measures, such as the widespread introduction of green technology and/or the adoption of consumption patterns with greatly reduced GHG footprints. What also seems to be necessary is that military action would affect the elimination of climate change ignorance and apathy within non-mitigating countries. How can military force affect these changes? Air campaigns as the current dominant mode of military coercion, say against coal energy plants, do not guarantee that greener technologies will

21. An exception is Lango, "Global Ethics and Global Climate Change." 
be chosen; instead, dirtier coal burning might result. An extensive air campaign would also be inadequate because it does not create green "hearts and minds." In short, regime change seems essential, and this requires troops on the ground as well as long-term political and cultural investments. The recent record of bringing about successful regime change through military force and aid is abysmal. It also raises the question: Which countries would deliver the military force and aid and would they be up to the task of changing "hearts and minds"?

Admittedly, it might be the case that the use of military force, or the threat thereof, as well as coercive economic and political measures, may motivate a country to make some changes in its environmental policies. Perhaps such actions, for example, may stop the burning of tropical forests, especially when neighboring countries would be directly affected, but the issue here is not whether coercion can make some difference on some occasions. Rather, I am contesting that military force is a convincing coercive instrument that may lead a country to transform from a non-mitigator to an important supporter of and contributor to, a global mitigation program such as the Paris Agreement.

The difficulties of a successful climate change mitigation war suggest that the proportionality principle might not be satisfied. A protracted war would be counter to the expected good of the war - greatly reduced GHG emissions - since war itself creates huge GHG emissions due to the fact that most mobile instruments of war are fuel-driven. An irony of the securitization of climate change is that the military is a major GHG emitter, in times of peace and especially when at war. ${ }^{22}$ Moreover, war is antithetical to reducing GHG emissions because refineries may be bombed, deforestation may occur, and, as previously noted, people may revert to cheaper and dirtier forms of energy, such as coal and dung, when energy grids are disrupted. It should also be noted that the production of the instruments of war involves high GHG emissions and the same is true of rebuilding the devastation that war typically leaves behind. So even if we would not incorporate other bad outcomes of war, such as the loss of human lives, the wounded, and the psychological casualties, and we would focus on GHG emissions alone, the bad results of war might outweigh its anticipated (but questionable) good results, and so a climate-change war might violate the principle of proportionality.

More specifically, some of the Gulf States, such as Kuwait and the United Arab Emirates,

22. The Pentagon is the largest single consumer of petroleum in the world and contributes as much as $5 \%$ of GHG emissions in the United States. See Sanders, The Green Zone: 51—53, 68. 
have the highest per capita emissions in the world. Now assume that these states continue with excessive fuel-driven consumption patterns and try to keep their market share by selling their oil cheaply. This would make them good candidates for military coercion. But then consider what happened during the Gulf War. The Iraqi troops withdrawing from Kuwait sought to destroy its resources, setting fire to hundreds of oil wells, which led to burning gas and oil for up to nine months, as well as to huge oil leaks on land and in the sea. A thousand people died because of smoke inhalation and the equivalent of several months of US GHG emissions went up in the air. ${ }^{23}$ It is not farfetched to assume that similar events might repeat themselves in protest against an UNSC-sanctioned military attack and occupation.

The two final just war principles for assessing resort to force with regard to nonmitigators are the just cause and last resort principles. I will briefly address the issue of last resort within the context of examining the just cause of UNSC-initiated war against nonmitigators. Two questions seem essential. First, is climate-change war the type of war that we recognize as conceivably having a just cause? Second, can we justify war against GHG nonmitigators in the sense that those individuals who enable their country to fall short in mitigation efforts are proper targets of force? In other words, is there something about these individuals who fail to address their GHG emissions or enable others to do so that justifies that violence is used against them or that their right to life is negated?

We have previously noted that the threat posed by climate change, although presently unfolding, is foremost an emerging threat, i.e., a threat that will increasingly materialize if very significant mitigation does not take place. Accordingly, it seems most plausible to view military force authorized by the UNSC against non-mitigators as a preventive war (rather than as a war of self-defense): non-mitigators may cause the collapse of the Paris Agreement and once this accord falls apart it will be much harder and costlier to avert severe or catastrophic climate change in the future, and success might be uncertain and, at best, partial. One problem with this argument for preventive war is that it is more convincing with regard to very large GHG emitters than small emitters and war is least feasible against them. Furthermore, there are two familiar objections to preventive war, say, as it has been defended in the context of preventing "rogue states" from acquiring nuclear weapons (and other WMD): Just war theory traditionally has defined a just cause as involving a wrong done and in the case of preventive war there is only a suspicion of a

23. See ibid., 110. 
future wrong; the principle of last resort is hard to satisfy since the anticipated wrong is a future wrong allowing for nonviolent measures to avert it. In the case of climate change preventive war, the problem that no wrong has been committed is less convincing since non-mitigation is an unfolding wrong and antithetical to climate change governance. Still, non-mitigating countries might promise to do much more at a later date, or they may engage in developing GHG absorption technologies, as well as new types of green energy, such as fusion, arguing that this is their contribution to the Paris Agreement. ${ }^{24}$ Such responses would make resort to force against these countries especially hard to justify. Relatedly, it is somewhat doubtful that the wrong done by small non-mitigators is really a threat to the Paris Agreement and could unravel it. After all, could other countries not compensate for the non-mitigators, increasing their mitigation efforts rather than opt for resort to force? Finally, the time frame of the dissolution of the Paris Agreement and the emergence of severe or catastrophic climate change is such that it becomes hard to stipulate that military force would be a last resort measure. There is enough time first to try diplomatic and non-military coercive measures and there is no clear point of when this endeavor should stop before the gathering dangers at the horizon allow no further delay of a military response.

Even if we grant that non-mitigation in some scenarios might constitute a definite threat to the Paris Agreement (or any other global climate accord) of a magnitude such that resort to force would be a just cause, the just cause principle also requires that the threat is of a kind (type) that warrants killing. Typically, millions of civilians of a non-mitigating state participate in creating its unacceptable GHG emissions, and it seems indefensible to claim that their conduct makes them liable to military attack. To be liable to attack one must be instrumental in the infliction of immediate life-threatening violence, making counter-violence necessary to protect lives. Similarly, it seems an error to argue that those who would protect the civilians from attack and seek to preserve the political self-determination of their community would in this way become morally liable to attack. In other words, the soldiers of a non-mitigating state are not morally liable to attack for defending their state. To be sure, this self-defense might be wrong in some cases, as when soldiers protect their own civilians engaged in acts of genocide, but in the case of civilian non-mitigators the wrong done by the civilians, unlike the wrong done by

24. For a criticism of technocratic approaches to climate change mitigation, see Klein, This Changes Everything, Part Two. Still, uncertainty about future technological possibilities may make it harder to justify military force against non-mitigators. 
genocidaires, is not of a nature that makes their protectors liable to attack. This leaves us with political and civilian leaders and their role in non-mitigation. If their support of non-mitigation expresses the popular will, then their shared responsibility does not make them liable to military attack. If the leaders act contrary to the popular will, then the appropriate response seems that the people should be encouraged to seek their replacement or overthrow. In my view, the only instances in which violence against non-mitigators might be appropriate is that the nonmitigating countries would respond violently against nonmilitary UNSC measures aimed at promoting mitigation or would brutally repress nonviolent individual actions in support of mitigation. The actions may be local or originate from other countries. Since GHG emissions have no borders and affect humanity as such, foreign protestors of the emissions of nonmitigating countries should be allowed to cross the borders of these countries and nonviolently express their opposition. The human rights of green nonviolent resisters, no matter their country of origin, should be protected by the global community, and harm against them should trigger coercive sanctions. By the same logic, non-mitigators have no right to refuse entry to climate refugees and the refugees should be protected from violence. In all these cases, the justificatory standards of defensive military force should be similar to those of traditional humanitarian intervention.

\section{6.}

Feminists have criticized the just war tradition and also articulated pacifist and nonpacifist alternatives. ${ }^{25}$ Let me briefly discuss how the feminist critique applies to the proposal of full securitization of climate change, focusing on two common criticisms of just war thinking in general. The first criticism is that just war thinkers tend to use abstraction in ways that turn us away from the particular horrors of wars. The focus in just war theory is on principles and abstract causes, not on violence against the body. Most glaringly, talk about "precision strikes," "strategic strikes," "collateral damage," and the like, move the mind away from burning flesh,

25. I hold that the feminist critique of just war theory should be used to improve just war theory. This is also the view of Peach, "An Alternative to Pacifism," 154, 164-67. More specifically, I have used this critique to support the view that just war theory needs to be supplemented by jus ante bellum (or just military preparedness) principles. See, for example, my "From Hiroshima to Baghdad." For additional articles on this topic, see http://works.bepress.com/harry_vanderlinden. 
exploding brains, and the like. ${ }^{26}$ Now in the case of the proposal of the full securitization of climate change, it seems that abstract talk about "force" and "threat" may lead us astray. A military threat is rather different from a climate threat, and military force is rather different from the force resulting from climate change. Hostility is one feature of this difference, making war violence in various degrees personal. A storm is not a "wind of hate." 27 There is also a difference in suddenness and immediacy, leaving victims physically and emotionally paralyzed. Interpersonal violence especially cuts off all options and terrorizes. It is, of course, this psychological feature of violence that makes people fear terrorism beyond any proportion of its actual harm. Focusing on the nature of military violence should lead us to become more constrained about when counter-violence might be justified. It is only when violence is physical violence that the defining features of violence come to the foreground, making counter-violence necessary and just, while when violence is only a metaphor or a resemblance of violence we should reject counter-violence. In other words, we should reject physical (subjective) violence as a response to "climate force," "climate threat," "ecological violence," and even "structural or systemic violence." 28

A striking example of viewing climate change as violence is to be found in Bill McKibben's recent essay "A World at War." He writes: "We're under attack from climate change.... World War III is well and truly underway. And we are losing.... Carbon and methane are seizing physical territory, sowing havoc and panic, racking up casualties, and even destabilizing governments... It's not that global warming is like a world war. It is a world war." He adds: "The question is not, are we in a world war? The question is, will we fight back? And if we do, can we actually defeat an enemy as powerful and inexorable as the laws of physics?" 29 For McKibben, we will only win the climate-change world war if the people would mobilize in a way similar to the total mobilization of the American people in response to the threat of fascism after Pearl Harbor during the Second World War. Then we responded with rapid and massive development of weapons industries; now we should respond similarly by immediately creating on a massive scale solar panels and wind turbines. Then the people swept aside the isolationist

26. See Peach, "An Alternative to Pacifism?," 158. See also Hun, "An Evaluation of Feminist Critiques of Just War Theory."

27. Cf. Grossman, On Killing, 76-82, who uses this expression to refer to the deep trauma of being confronted with hostility, as distinct from threats lacking hostile intent.

28. See in more detail in my "On the Violence of Systemic Violence."

29. McKibben, "A World at War," 
"America Firsters"; now we must sweep aside the lack of cooperation and obstructionist policies of fossil-fuel industries. And, finally, we should not think that the Paris Agreement is victory and will take care of the unfolding threat of a world at war, replicating Chamberlain's misguided hope after Munich.

What is misleading about this analysis is that the anthropogenic character of climate change disappears: the enemy is "carbon and methane," not, say, the fossil-fuel industries and factory farming. It is easy to see why McKibben argues this way: he has no place for soldiers killing those causally responsible for climate change. This is fair enough, but then the notion of climate change as war should be set aside. This notion also obfuscates the different character of military attacks and its harms and the operations of climate change and its negative impacts. Indeed, McKibben seems to indirectly acknowledge this latter point when he notes that one problem with the war of climate change is that there is no Pearl Harbor moment, mobilizing the people to fight against this war. McKibben appeals to a familiar idea that only war can push people to unite and concentrate their efforts on a common goal. There is some sad truth in this, but the idea neglects that war also creates hatred, virulent nationalism, etc. At any rate, the reference to World War II mobilization is flawed in that it is unlikely that the US government will direct and coordinate the fight against the "enemy", as happened in World War II. ${ }^{30}$ Instead, it seems that organizing from below by environmental groups needs to (continue to) play a pivotal role, including obstruction of governmental policies and business practices counter to GHG mitigation. Another problem is that the portrayal of climate change as war suggests that optimal weapons (solar, wind, electric cars, etc.) are crucial to winning the "war," neglecting that the broader issue is how capitalist society focused on growth and profit maximization is continuously undermining the natural environment conducive to human flourishing. In other words, we need not only a technological transformation but also a value transformation. ${ }^{31}$

This points to a second feminist critique of the just war tradition. In the words of Carol Cohn and Sara Ruddick, the critique is that "just war theorists tend to abstract particular wars

30. Accordingly, calls for a World War II mobilization without describing climate change as a war are also flawed. In Unprecedented Climate Mobilization, Woodworth and Griffin make such a call (26-53) and also discuss prior similar calls made during the past decade (39-41). More promising are their suggestions for nonviolent citizen strategies to transform the status quo (91-108).

31. Cf. Godoy and Jaffe, "We Don't Need a 'War' on Climate Change." I am sympathetic to their view that what is needed instead of war is revolution, but it goes beyond the scope of this chapter to argue for this claim. Of course, my criticism of McKibben here is only directed against his essay "A World at War," and not against his broader work and activism. 
from the war system on which they rely and which they strengthen." This "war system" involves: "arming, training, and organizing for possible wars; allocating the resources these preparations require; creating a culture in which wars are seen as morally legitimate, even alluring; and shaping and fostering the masculinities and femininities that undergird men's and women's acquiescence to war." ${ }^{32}$ In terms of the securitization of climate change, the problem is that the neglect of the war system involves a neglect of how the preparation for war, materially and culturally, is antithetical to realizing strong GHG mitigation goals. We have already touched upon the material opposition between weapons production and testing, and fighting, on the one hand, and GHG mitigation on the other hand. The cultural opposition is that the dominant morality of war as an ethics of control, domination, hierarchy, and expansion seems rather opposed to the type of individual and social green ethics required to turn around climate change, that is, an ethics of simplicity, limitation, and humility concerning our place in nature. ${ }^{33}$ It also must be an ethics of resistance, but one that seeks, with an eye on future reconciliation, nonviolent action (protest, noncooperation, civil disobedience, and nonviolent intervention) toward opposing forces rather than their destruction.

\section{7.}

In conclusion, the U.N. Charter aimed "to save succeeding generations from the scourge of war," and it is certainly the case that climate change is a "threat multiplier" and may play a significant role in bringing about future conflicts. Still, the view of climate change as a threat to peace warranting UNSC authorization of military force to reduce the threat is mistaken. The harms of climate change and the violence of humans should not be equated, and mitigation wars will be counterproductive and in violation of just war norms. The idea that the UN Security Council can rescue us from severe or catastrophic climate change by enforcing a global mitigation schema is implausible and strengthens both materially and culturally the existing war system. War will indeed result when global mitigation fails, but it is likely to be war to maintain access to resources and arable land as well as to keep climate refugees out of the affluent countries. The best safeguard against a future of military eco-apartheid is a mass movement of

32. Cohn and Ruddick, "A Feminist Ethical Perspective on Weapons of Mass Destruction," 406.

33. Cf. Jamieson, Reason in a Dark Time, 186-87. More bellicose and realist understandings of just war theory seem to adhere to this morality of war, while Peach's feminist reconceptualization of just war theory seems closer to embracing the values of a green ethics. 
nonviolent resistance, solidarity, and green virtues and values. ${ }^{34}$ This movement should also materialize and strengthen its commitment to a future livable world by creating now the world we need, a world of socialized renewable energy networks. ${ }^{35}$

\section{Bibliography}

Boffey, Daniel, and Arthur Nelsen, "China and EU respond to Trump with a new climate alliance." Irish Times, June 1, 2017.

Campbell, Kurt M., and Christine Parthemore, "National Security and Climate Change in Perspective." In Climate Cataclysm, edited by Kurt M. Campbell. Washington, D.C., Brookings Institution Press, 2008.

Christiansen, Silke Marie. Climate Conflicts. Switzerland, Springer International Publishing, 2016.

Climate Action Tracker. "Global Temperatures.” http://climateactiontracker.org/global/temperatures/.

Climate Action Tracker, "Rating countries." http://climateactiontracker.org/countries.html.

Climate Home. "UN Security council hears climate fears of small island states." http://www.climatechangenews.com/2015/07/31/un-security-council-hears-climate-fears-of-smallisland-states/.

Godoy, Eric S., and Aaron Jaffe. "We Don't Need a 'War' on Climate Change, We Need A Revolution." New York Times, October 2016.

Cohn, Carol, and Sara Ruddick. "A Feminist Ethical Perspective on Weapons of Mass Destruction.” In Ethics and Weapons of Mass Destruction, edited by Sohail H. Hashmi and Steven P. Lee. Cambridge: Cambridge University Press, 2004.

Cousins, Stephanie. "UN Security Council: playing a role in the international climate change regime?" Global Change, Peace \& Security 25:2 (2013): 191-210.

Gilley, Bruce, and David Kinsella. “Coercing Climate Action.” Survival 57 (April-May 2015): 7-28.

Grossman, David, Jr. On Killing. Boston, Little, Brown and Company, 1995.

Hun, Sinem. “An Evaluation of Feminist Critiques of Just War Theory.” DEP (2014): 76-84. http://www.unive.it/media/allegato/dep/n24-2014/Ricerche/05_Hun.pdf.

34. For the notion of "eco-apartheid," see Malleson, "A Community-Based Good Life or Eco-Apartheid." Again, in the final instance, it must be moral strength rather than military might that must save us from severe or catastrophic climate change, but those with the huge arsenals have an interest in convincing us otherwise. Cf. Pogge, "Poverty and Violence," 109-10, who argues against military violence against wealthy countries for the sake of reducing the global poverty in which they are implicated.

35. See Mann, "On the Precipice with Naomi Klein, Karl Marx, and the Pope." 
Jamieson, Dale. Reason in a Dark Time. Oxford: Oxford University Press, 2014.

Klein, Naomi. This Changes Everything. New York: Simon \& Schuster, 2014.

Lango, John W. "Global Ethics and Global Climate Change: What Should the Security Council Do?" Presented at the Political Studies Association, 2009, n.p.

Malleson, Tom. “A Community-Based Good Life or Eco-Apartheid.” Radical Philosophy Review 19/3 (2016): 593-619.

Mann, Patricia S. "On the Precipice with Naomi Klein, Karl Marx, and the Pope: Towards a Postcapitalist Energy Commons and Beyond.” Radical Philosophy Review 19/3 (2016): 621-652.

McKibben, Bill. “A World at War.” New Republic, August 2016. https://newrepublic.com/article/135684/declare-war-climate-change-mobilize-wwii.

Ng, Trina. "Safeguarding Peace and Security in our Warming World: A Role for the Security Council." Journal of Conflict \& Security Law 15 (2) 2010: 275-300.

Peach, Lucinda J. “An Alternative to Pacifism? Feminism and Just-War Theory.” Hypatia 9 (Spring 1994): 152-72.

Pogge, Thomas. "Poverty and Violence.” LEAP 1 (2013): 87-111.

Sanders, Barry. The Green Zone. Baltimore: AK Press, 2009.

Scott, Shirley V. "Implications of climate change for the UN Security Council: mapping the range of potential policy responses." International Affairs 91 (5), 2015: 1317-1333.

Scott, Shirley V. "The Securitization of Climate Change in World Politics: How Close have We Come and would Full Securitization Enhance the Efficacy of Global Climate Change Policy?" Review of European Community \& International Environmental Law 21 (3) 2012: 220-30.

Van der Linden, Harry. "From Hiroshima to Baghdad: Military Hegemony versus Just Military Preparedness." In Philosophy after Hiroshima, edited by Edward Demenchonok. Newcastle on Tyne, UK: Cambridge Scholars Publishing, 2010.

Van der Linden, Harry. “On the Violence of Systemic Violence: A Critique of Slavoj Žižek.” Radical Philosophy Review 15 (2012): 33-51.

Woodworth, Elizabeth, and David Ray Griffin. Unprecedented Climate Mobilization. Atlanta: Clarity Press, 2016.

Young, Iris Marion. Responsibility for Justice. Oxford: Oxford University Press, 2011. 